\title{
Effect of Rewetting on Smouldering Combustion of a Tropical Peat
}

\author{
Afiri Dianti ${ }^{1, *}$, Nadhira Gilang Ratnasari ${ }^{1}$, Pither Palamba $^{1}$, and Yulianto Nugroho ${ }^{1}$ \\ ${ }^{1}$ Department of Mechanical Engineering, Faculty of Engineering, Universitas Indonesia, Kampus UI Depok 16424, Indonesia
}

\begin{abstract}
Probability of land and forest fire in Indonesia is quite high. Peat land is one of the highest contribute of the fire disaster. Indonesia is the country with the highest peat land in Southeast Asia, with more than $50 \%$ of tropical peat species. Combustion of peat produced carbon emission with large quantities and affect to global warming. Characteristic of smoldering combustion of peat cause detection and extinction be difficult. Moreover, there are another impact such as high erosion potential, structural collapse and soil layer damage. Flameless on peat smoldering causes peat restoration institution build fire prevention method. Regulation of water table on peat land with rewetting method aims to maintain and restore the moisture of peat. The experiment aims to understand characteristic of smoldering combustion of rewetting peat. Sample used in the experiments was taken from Bagaiserwar village, Sarmi, Papua (01 $55^{\prime} 14,11^{\prime \prime}$, E: $\left.138^{\circ} 6^{\prime} 17,35^{\prime \prime}\right)$. A set of thermocouples were used to explore horizontal spread rate at $80 \mathrm{~mm}$ intervals. Mass loss rate indicates derivation caused by evaporation on wet peat. Author discovered a fire risk is higher than natural combustion in experiments with rewetting peat. Spread rate of smoldering is high on rewetting peat with initial MC before rewetting is $\leq 10 \%$. Hydrophobic of peat cause retention of water on peat changes. This phenomenon causes evaporation process being faster and total combustion time occur rapidly, start from preheating until self extinction.
\end{abstract}

\section{Introduction}

Probability of land and forest fire in Indonesia is quite high. The statement was proven in the last ten years, which Indonesia had been through fire crisis. In the year of 1997 - 1998, Indonesia encountered a huge fire disaster, which is damage more than 11 million hectare of land and forest, and affect to economic losses, biodiversity, supply of water and ecosystem [1]. Product of land and forest fire is toxic gas, which affect to environmental, especially human health. Carbon emission that is produced by combustion could release to atmosphere and affect to global warming [2]. Forest fire in Sumatera, Indonesia, 1997, was emit carbon in the amount of $0.81-2.57 \mathrm{Gt}$, that mostly from peat land [3]. Adverse impact in other aspects are economic losses for another countries, are neighboring countries. Based on these cases, effect of peat fire is quiet serious and need advanced actions.In global, Indonesia takes the fourth position of the widest peat land, over Canada, Russia, and US[4]. Indonesia is the country with the highest peat land in Southeast Asia, with more than $50 \%$ of tropical peat species. Indonesia has $225,000 \mathrm{~km}^{2}$ of peat land, which mostly in Kalimantan, with total area is 57,600 and $30,100 \mathrm{~km}^{2}[1]$.

\footnotetext{
Corresponding author: yulianto.nugroho@ui.ac.id
}

Type of peat in Indonesia is dominated by sulfur element content and low ash, about $60 \%$ of the world's largest ombrogenous peat could be found in Indonesia [5]. At the time of ignition on organic soil or vegetation, fire could be sustain to burning constantly and spread to all direction, either flame or flameless. Smoldering combustion in underground layer on land and forest might not show the ignition of fire combustion, such flame. However, the impacts of the phenomenon are high erosion potential, structural collapse and soil layer damage [6]. Ramadhan said that a peat with a different origin region show heterogeneous of smoldering pattern. The difference is caused by effect of density, porosity, thermal conductivity and heat capacity[7]. While peat has through evaporating or combusting, ability of water absorption is decrease. Dry peat could not absorb and store fluid in porous back to the initial. Peat restoration institution builds fire prevention method of fire potential peat land. Regulation of water table on peat land with rewetting method aims to maintain and restore the moisture of peat. The proceedings of the method are could be construction of channel canals, drainage, drilling wells, and water retention [8]. Based on this prevention method, author would like to know the effect of rewetting method on smoldering combustion that could happen. Moreover, fire risk of potential land would be predicted well. 


\section{Materials and methods}

\subsection{Material sample}

In this experiment, material sample that used for combustion and rewetting is a tropical peat, which from Indonesia. Peat sample are obtained from Bagaiserwar village, Sarmi, Papua (015' 14, 11', E: 1386'17, 35”). Fig. 1 shows peat sample that through drying process before. Peat was dried by oven at $104^{\circ} \mathrm{C}$ at 24 hours. Drying process is used to evaporate the water from peat, then the moisture content of peat could be decrease until $\leq 10 \%$. To know the fire risk of rewetting peat, variation of rewetting method is done. Rewetting peat was applied to different sample of Bagaiserwar peat. Rewetting peat as barrier has a different MC with dry peat. In the first, wet peat has $\mathrm{MC} \pm 90 \%$, which the sample is initial soil. Another variable, dry peat $(\mathrm{MC} \leq 10 \%)$ was rewetted and has $\mathrm{MC} \pm 60 \%$. Drying process before rewetting is affect to characteristic of peat. Irreversible drying in peat makes ability of absorption is decrease and could not back to initial[9]. Before the experiment begin, sample was stored in container for 72 hours for equalize moisture content of peat.

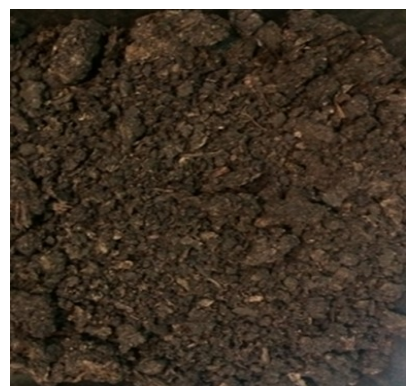

Fig. 1. Bagaiserwar Peat after dried at $104^{\circ} \mathrm{C}$ for 24 hours

\subsection{Method}

In this experiment, dry peat was burned in stainless steel equipment with calciboard as boundary plat. Design of set box is rectangular with dimension $21 \mathrm{~cm} \mathrm{x} 10 \mathrm{~cm} \mathrm{x}$ $12 \mathrm{~cm}$ for dry peat and $36 \mathrm{~cm} \times 26 \mathrm{~cm} \mathrm{x} 4 \mathrm{~cm}$ for rewetted peat. The reactor was designed to understand the horizontal spread of smoldering. To initiate smouldering front, coil igniter is turned on at $100 \mathrm{~W}$ for one hour on top of layer (20 $\mathrm{mm}$ from surface). To explore the horizontal smoldering, the use of 16 thermocouple at variation of 3 distances $(25 \mathrm{~mm}, 105$ $\mathrm{mm}, 185 \mathrm{~mm}$ from coil igniter) dan 6 depths $(20 \mathrm{~mm}, 40$ $\mathrm{mm}, 60 \mathrm{~mm}, 80 \mathrm{~mm}, 100 \mathrm{~mm}, 120 \mathrm{~mm}$ of dry peat surface), with the configuration shown by Fig. 2. To examine the mass loss from smoldering combustion on peat, mass changes measured at $60 \mathrm{~s}$ intervals. The density of the sample was $\pm 0.210 \mathrm{~g} / \mathrm{cm}^{3}$ for dry peat and $\pm 0.391 \mathrm{~g} / \mathrm{cm}^{3}$ for rewetted peat. After coil igniter was turned off, the peat sample were allowed to burn until extinguish caused by running out of peat as fuel.

\section{Results and discussion}

\subsection{Temperature and horizontal spread rate profile}

Temperature data of sample peat in this experiment show smoldering phenomenon. Fig. 3 shows smoldering combustion on tropical peat as baseline. On the baseline experiment figure, smoldering combustion could examine after heater was turned off. Sample peat undergoes preheating and pyrolisis process, thus oxidation combustion. This is indicated by temperature data, with preheating region at $80^{\circ} \mathrm{C}-100^{\circ} \mathrm{C}$, pyrolisis at $250^{\circ} \mathrm{C}-300^{\circ} \mathrm{C}$, and oxidation at more than $350^{\circ} \mathrm{C}$ [10]. The propagation takes place vertically faster than horizontal propagation[7]. This qualitative analysis was from temperature on $25 \mathrm{~mm}$ from heater at all depths was increase rapid than others. On surface layer (0-20 $\mathrm{mm})$, temperature has fluctuations in temperature increase. However the supply of oxygen on surface area is much more than the underground, the amount of heat loss due to the wind on surface makes smoldering is slow. Bagaiserwar peat needs \pm 20 hours from ignition to self-extinguish on baseline experiment. On $80-100$ $\mathrm{mm}$ of peat layer from surface, burning region is on the longest time. Fig. 3, 4 and 5 shows total of time of smoldering combustion that is needed in experiments is showing the difference. A time difference between baseline and rewetting MC $90 \%$ of Bagaiserwar peat is 2 hours.
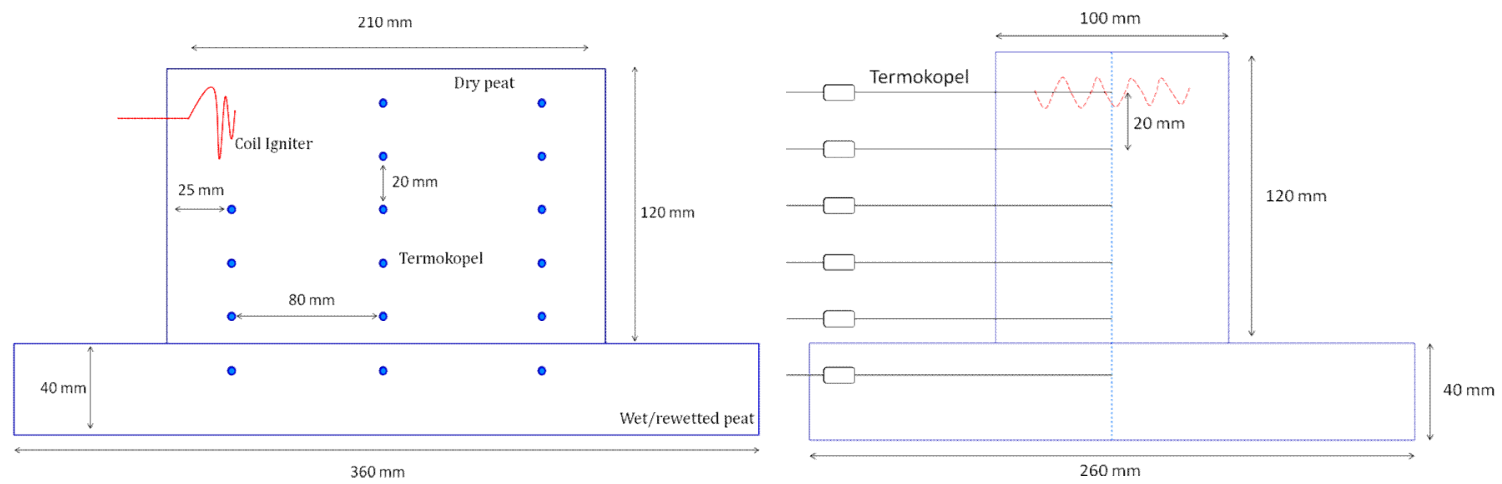

Fig. 2. Reactor of peat smoldering experiment and configuration of thermocouples 


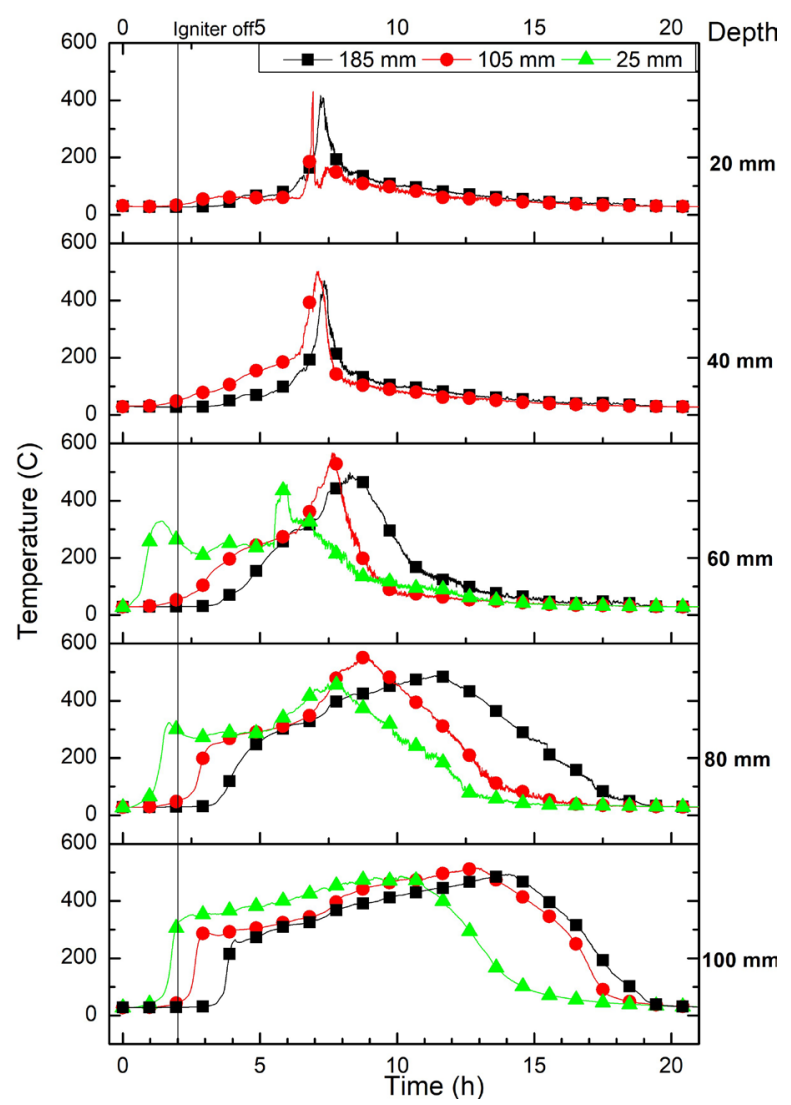

Fig. 3. Temperature measurement from baseline experiment on Bagaiserwar peat

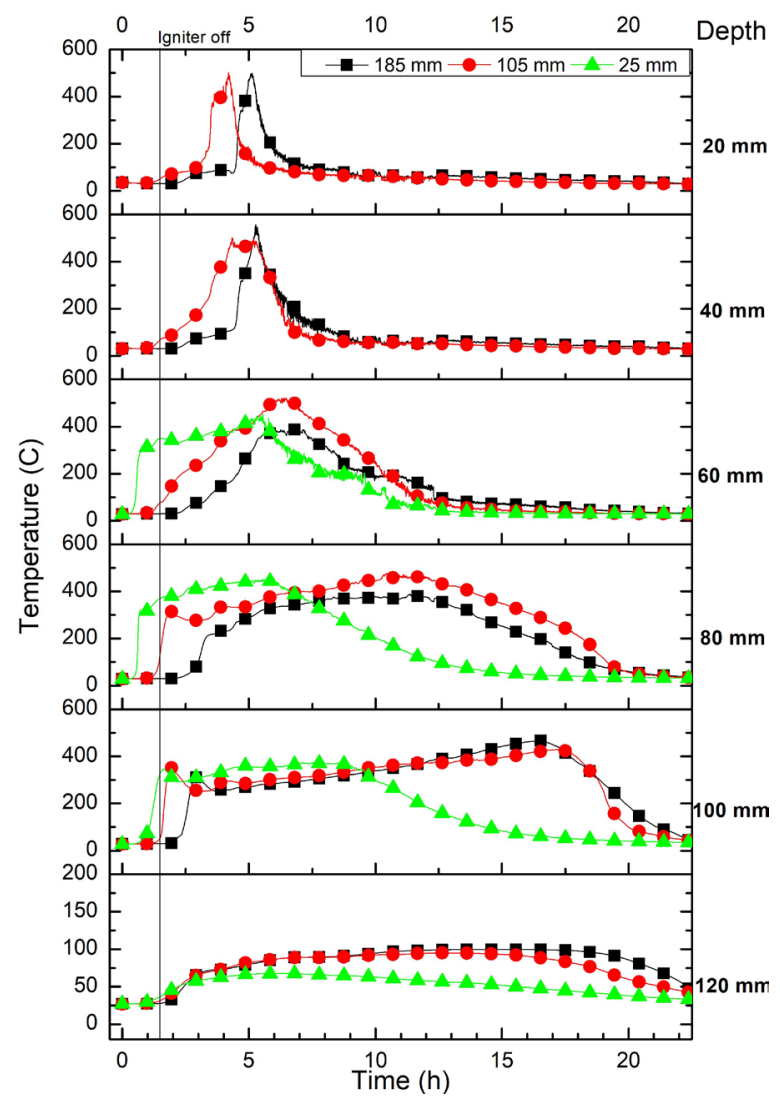

Fig. 4. Temperature measurement from rewetting experiment on Bagaiserwar peat using wet peat $\mathrm{MC} \pm 90 \%$ 


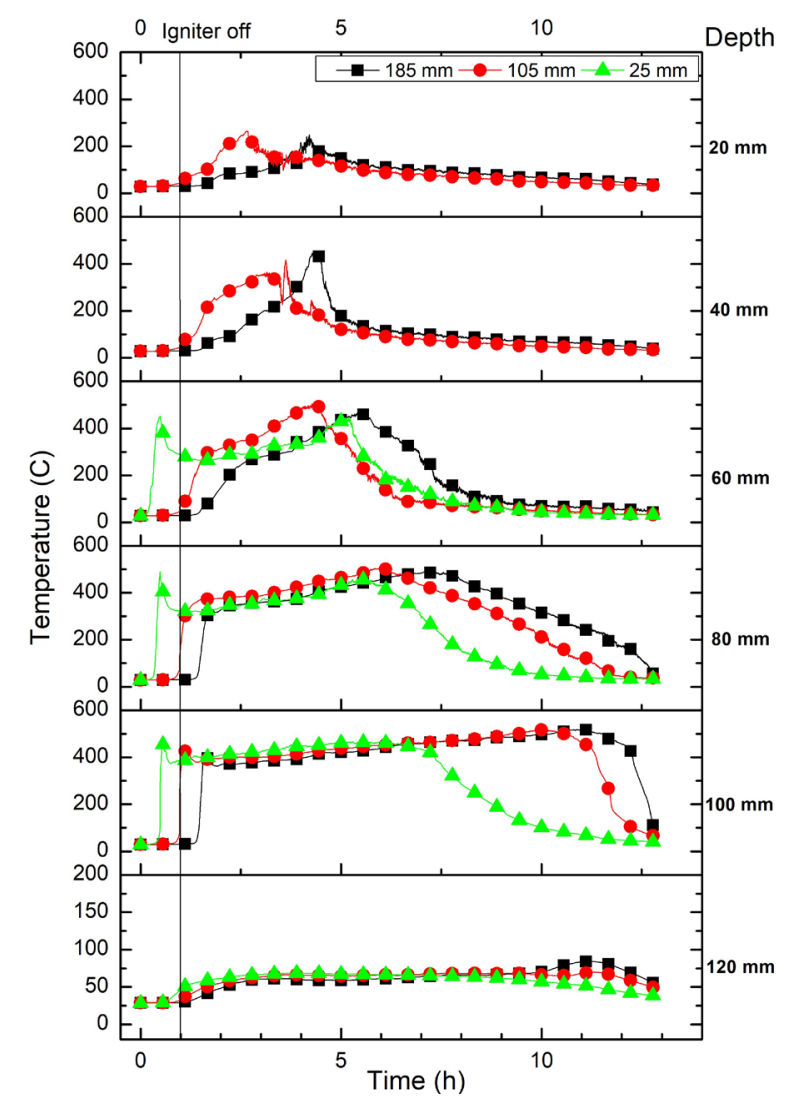

Fig. 5. Temperature measurement from rewetting experiment on Bagaiserwar peat using wet peat $\mathrm{MC} \pm 60 \%$

The difference is caused by amount of fuel for combustion is much more for rewetting experiment. Thus, heat from oxidation not only affect to dry peat sample, but also rewetted peat. Lowering on peat layer is effected by mass loss on underground. For rewetting experiment on using wet peat $\mathrm{MC} \pm 60 \%$, Bagaiserwar peat only needs 13 hours for total combustion time, until self-extinguish.

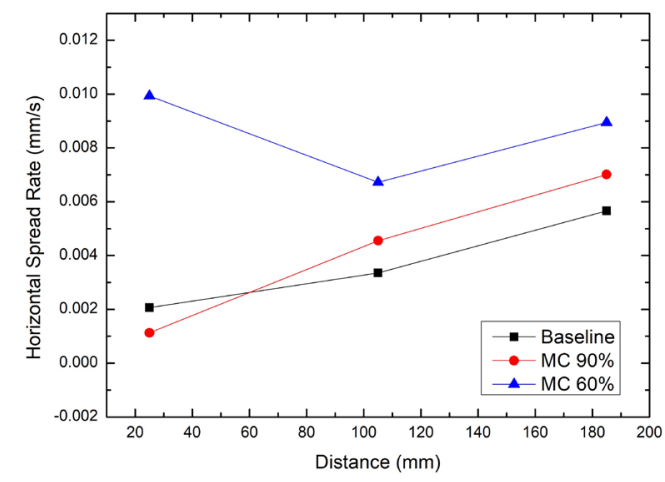

Fig. 6. Horizontal spread rate profile of and Bagaiserwar peat

This shows smoldering spread occurred rapidly, and triggering ignition on another zone in short time. Based on the maximum temperature on the distance of the heater, it can be seen the rate of smoldering propagation horizontally. Fig. 6 shows spread rate profile of Bagaiserwar peat on all experiments. In accordance with the total time required, the propagation rate shows correlated results. Rapid combustion on rewetting experiment on Bagaiserwar using wet peat $\mathrm{MC} \pm 60 \%$, caused by characteristic of rewetted peat, below dry peat sample. Even though the moisture content of wet peat is smaller, the water of rewetting is probably not stored well in porous of peat. The water is on the surface of peat caused by the permeability properties lost. As a result, during the combustion experiment, the water will evaporate rapidly and oxygen will fill the gap. The magnitude of the gap in wet peat affects the large supply of oxygen obtained by dry peat sample. In the rewetting experiment, temperature data was also measured on rewetted peat, with a distance equal to other depths (25 $\mathrm{mm}, 105 \mathrm{~mm}$, and $185 \mathrm{~mm}$ of heater). During the experiment, temperature of rewetted peat does not reach more than $100^{\circ} \mathrm{C}$. This indicates that the zone undergoes a process of evaporation. The evaporation process is evidence by moisture content change on rewetted peat[9]. In the rewetting experiment using wet peat MC $90 \%$, Bagaiserwar peat undergoes a moisture content change of $6.12 \%$, from $90.07 \%$ decrease to $83.95 \%$. 

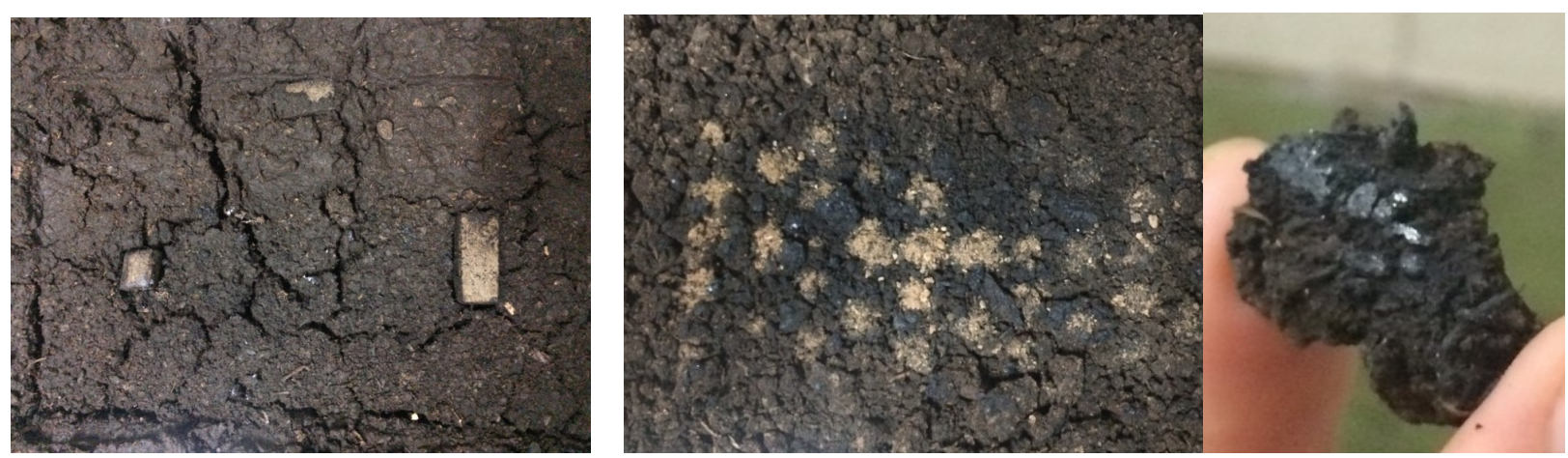

Fig. 7. Rewetted peat after the rewetting experiment. MC $90 \%$ (left), MC $60 \%$ (right)

Unlike experiment using wet peat MC 60\%, moisture content change is very significant for Bagaiserwar peat, because moisture content change reached $58.5 \%$, from $64.22 \%$ decrease to $5.72 \%$. The process that occurs in the rewetted peat MC $90 \%$ was fracture, while MC $60 \%$ is char formation, as Fig.7. The temperature on this zone does not show the oxidation process which is $\geq 350^{\circ} \mathrm{C}$, and also pyrolisis process $\left(200^{\circ} \mathrm{C}-350^{\circ} \mathrm{C}\right)$. However, visually, the surface layer of the rewetted peat after experiment results in the formation of char.

Peat restoration institution used rewetting method for peatland to maintain the moisture of soil layer. The purpose of this method is to continue the revegetation and revitalization. However, a high propagation rate in this experiment indicates a high risk of fire hazard. The magnitude of the propagation illustrates the scheme of peat land fires that will spread rapidly, although there is a dry peat that has undergone rewetting as barriers.

\subsection{Mass loss rate}

Based on the comparison of temperature graphs over time on all experiment, the combustion pattern has the same stages. Starting from the preheating region, where peat undergoes evaporation, pyrolisis to char and ash formation. During this burning process, peat soil mass will be more lost. The evaporation process will remove water from the peat pores, both macro and micro pores. Water will evaporate at temperature $\pm 100^{\circ} \mathrm{C}[10]$. Thus, the mass loss corresponds to the moisture content. Not only the formation of water vapor that contributes the mass loss, the organic content is burned as well and produce gas at pyrolisis also decrease the mass[10]. Fig.8. shows the graph of the mass loss rate against time is measured throughput the experiment.

The mass measured in experiments consists of dry peat and wet peat. Whereas, in burning experiment without rewetted peat (baseline) only measure mass data of dry peat. In Bagaiserwar peat, the highest mass loss rate is in rewetting experiment using rewetted peat MC $60 \%$, where the maximum value reaches \pm 270 gram/hour. The water in rewetting experiment (MC $60 \%$ ) is not completely absorbed, even the water is in the peat surface envelope, so water will quickly evaporate. A great contribution of this mass loss is evaporation of water of rewetted peat. The lower mass loss rate over time, over 10 hours, indicates fuel limitations due to the combustion oxidation reaction process.

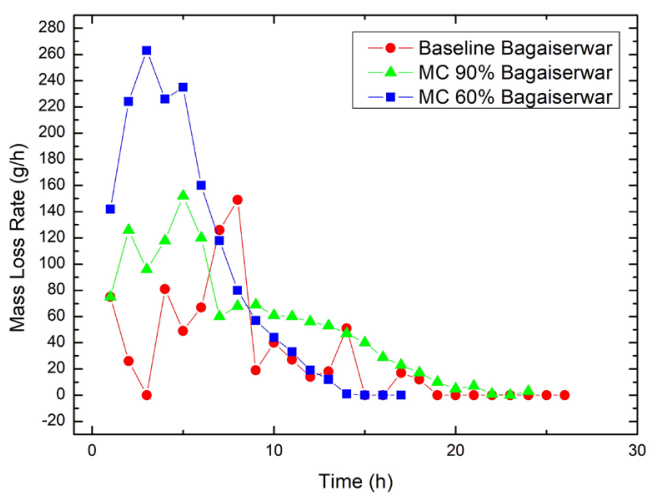

Fig. 8. Mass loss rate of Bagaiserwar peat 


\section{Conclusions}

Through the series experiments, it can be found that there is influence of rewetting method to smoldering combustion. The rewetting method applied to dry peat indicates the irreversible drying properties that accelerate the evaporation process when given the heat. The loss of water mass on the wet peat provides a gap in the oxygen supply to accelerate combustion. The highest horizontal spread rate is in the rewetting experiment on the Bagaiserwar peat, which is $\pm 0.010 \mathrm{~mm} / \mathrm{s}$. Characteristics of these peat affect to combustion time. The properties of inorganic content and porosity are related to the rate of smoldering. The length of time for peat undergoes combustion, could be a potential risk for forest fire. This shows the rewetting method is not effective for Bagaiserwar peat, seen from fire risk. On the other hand, further studies on rewetting method of peat still needs to be carried out to provide a better understanding of smoldering combustion on peat.

The authors would like to thank Ministry of Research, Technology, and Higher Education of the Republic of Indonesia and Universitas Indonesia for the financial support through the Penelitian Terapan Unggulan Perguruan Tinggi (PTUPT) 2018 with contract number 514/UN2.R3.1/ HKP05.00/2018.

\section{References}

1. Hayasaka, H., et al., Peat-fire-related air pollution in Central Kalimantan, Indonesia. Environmental pollution, 195: p. 257-266 (2014)

2. Lestari, A.K.P., Measurement of PM10 and Black Carbon Concentration Emitted by Smoke from Peat Land and Forest Fire in Desa Pekanheran, Kabupaten Indragiri Hulu, Provinsi Riau. Jurnal Teknik Lingkungan, 17(Nomor 1): p. 100 - 111 (2011)

3. Page, S.E., et al., The amount of carbon released from peat and forest fires in Indonesia during 1997. Nature, 420(6911): p. 61 (2002)

4. Agus, F. and I.M. Subiksa, Lahan Gambut: Potensi untuk pertanian dan aspek lingkungan. Balai Penelitian Tanah dan World Agroforestry Centre (ICRAF), Bogor (2008)

5. Edi, M. and W.T. Nurul, Mechanism And Reaction Kinetics Of Peat Decomposition (2011)

6. Rein, G., et al., The severity of smouldering peat fires and damage to the forest soil. Catena, 74(3): p. 304-309 (2008)

7. Ramadhan, M.L., et al., Experimental study of the effect of water spray on the spread of smoldering in Indonesian peat fires. Fire Safety Journal, 91: p. 671-679 (2017)

8. Wibisono, I.T.C. and A. Dohong, Panduan Teknis Revegetasi Lahan Gambut, Badan Restorasi Gambut Republik Indonesia (2017)
9. Perdana, L., et al. Hydrophilic and hydrophobic characteristics of dry peat. in IOP Conference Series: Earth and Environmental Science. IOP Publishing (2018)

10. Rein, G., S. Cohen, and A. Simeoni, Carbon emissions from smouldering peat in shallow and strong fronts. Proceedings of the Combustion Institute, 32(2): p. 2489-2496 (2009) 